\title{
PERANCANGAN MEDIA SIAP UN MATEMATIKA SMP BERBASIS ANDROID
}

\author{
Mugi Jayanti ${ }^{1}$, Yogi Wiratomo ${ }^{2}$ \\ Program Studi Pendidikan Matematika, Universitas Indraprasta PGRI ${ }^{1}$ \\ Email:mujayanti9@gmail.com ${ }^{1}$ \\ Program Studi Pendidikan Matematika, Universitas Indraprasta PGRI ${ }^{2}$ \\ Email: yogiwiratomo@ymail.com²
}

\begin{abstract}
Abstrak
Kebiasaan siswa dalam penggunaan perangkat elektronik untuk permainan dan sosial media dapat menurunkan mutu pendidikan, seperti yang terlihat pada hasil UN SMP yang kurang memuaskan. Untuk itu perlu ditingkatkan dengan memperbanyak latihan dan dengan melihat kebiasaan siswa menggunakan perangkat elektroniknya. Tujuan penelitian ini adalah untuk mengembangkan media edukatif berbasis android sebagai media pembelajaran latihan soalsoal ujian nasional untuk peserta didik tingkat SMP dan mengetahui kelayakan media edukatif berbasis android sebagai media pembelajaran latihan soal-soal ujian nasional berdasarkan validasi atau penilaian dari ahli materi, ahli media, dan praktisi pembelajaran matematika. Penelitian ini merupakan jenis penelitian dan pengembangan (Research and Development) dengan mengikuti model pengembangan ADDIE (Analysis, Design, Development, Implementation, Evaluation) yaitu tahap analisis, desain, pengembangan, implementasi, dan evaluasi, namun hanya dilaksanakan hingga tahap keempat, yaitu implementasi. Validasi media dilakukan oleh ahli materi, ahli media, dan praktisi pembelajaran matematika yaitu Guru Matematika MTs. Teknik pengumpulan data dalam penelitian ini menggunakan angket. Data yang diperoleh dari angket kemudian dianalisis secara deskriptif, kualitatif dan kuantitatif. Hasil penelitian menunjukkan bahwa media edukatif "Siap UN SMP" berbasis android yang dikembangkan ini sangat layak digunakan sebagai media pembelajaran latihan soal-soal ujian nasional tingkat SMP.
\end{abstract}

Kata kunci: Pengembangan media pembelajaran, UN SMP, android

\begin{abstract}
Students' habitof using electronic devices for games and social media can reduce the education quality, as seen in the less satisfactory results of Junior High School National Examination. To improve this result, it is necessary to give students more exercises while considering their habit of using electronic devices. This research aims to develop an android-based educational medium for practicing doing National Examination questions for Junior High School Studentsand to determine its eligibility based on validation and evaluation by subject experts, media experts and practitioners of mathematics learning. The type of the research is research and development performed based on the development model ADDIE (Analysis, Design, Development, Implementation, Evaluation),but only conducted until the fourth stage (implementation). Media validation is conducted by subject experts, media experts and practitioners of mathematics learning in MTs (Madrasah Tsanawiyah). Data are collected by distributing a questionnaire and then analyzed descriptively, qualitatively and quantitatively. The result show sthe android-based medium "Siap UN SMP" is very suitable to use as a medium for practicing doing questions of National Examination at Junior High School Level.
\end{abstract}

Keyword: Learning mediumdevelopment, Junior High School National Examination, android

\section{Pendahuluan}

Sebagai salah satu wahana pembentuk karakter bangsa, sekolah adalah lokasi penting di mana para "Nation Builders" dapat mengasah kemampuan dan diharapkan dapat bersaing di kancah global. Seiring dengan derasnya tantangan globalisasi saat ini, tantangan dunia 
pendidikan pun menjadi semakin besar, hal ini juga yang mendorong para peserta didik untuk memiliki prestasi terbaik. Belajar di Sekolah menjadi pola umum kehidupan warga masyarakat di Indonesia. Dewasa ini keinginan hidup lebih baik telah dimiliki oleh warga masyarakat. Belajar telah dijadikan alat hidup. Wajib belajar selama sembilan tahun merupakan kebutuhan hidup. Oleh karena itu, warga masyarakat mendambakan agar anakanaknya memperoleh tempat belajar di sekolah yang baik.

Namun, untuk maju di dunia modern seperti sekarang ini bukan hanya pendidikan saja yang diperlukan, melainkan juga peningkatan sumber daya manusia dalam penguasaan teknologi. Pengaruh IPTEK sejauh ini berdampak besar dalam membantu aktivitas manusia. Oleh karena itu, pemerintah harus pandai-pandai memajukan IPTEK dengan disertai pengembangan SDM di Indonesia.

Matematika merupakan ilmu universal yang mendasari perkembangan teknologi modern, mempunyai peran penting dalam berbagai disiplin dan memajukan daya pikir manusia. Perkembangan pesat di bidang teknologi informasi dan komunikasi dewasa ini dilandasi oleh perkembangan matematika di bidang teori bilangan, aljabar, analisis, teori peluang dan matematika diskrit. Untuk menguasai dan menciptakan teknologi di masa depan diperlukan penguasaan matematika yang kuat sejak dini, oleh karena itu mata pelajaran Matematika perlu diberikan kepada semua peserta didik dari dini untuk membekali peserta didik dengan kemampuan berpikir logis, analitis, sistematis, kritis, dan kreatif, serta kemampuan bekerjasama. Kompetensi tersebut diperlukan agar peserta didik dapat memiliki kemampuan memperoleh, mengelola, dan memanfaatkan informasi untuk bertahan hidup pada keadaan yang selalu berubah, tidak pasti, dan kompetitif.

Teknologi komunikasi yang ada saat ini juga bisa dimanfaatkan oleh masyarakat Indonesia sebagai peluang dalam menghadapi MEA. Hal ini terlihat dari banyaknya pengguna internet di Indonesia. Kementerian Komunikasi dan Informatika (Kemkominfo) menyatakan, pengguna internet di Indonesia hingga saat ini telah mencapai 82 juta orang, dan Indonesia berada pada peringkat ke- 8 di dunia. Dari jumlah pengguna internet tersebut, 80 persen di antaranya adalah remaja berusia 15-19 tahun, kategori usia sekolah antara SMP dan SMA.

Kebanyakan dari remaja saat ini mengakses internet melalui smartphone. Handphone pintar yang telah dilengkapi dengan berbagai fitur dan aplikasi menarik serta dapat diunduh secara gratis melalui app store yang didukung oleh perangkat $i O S$ ataupun playstore yang didukung oleh perangkat Android. Android sendiri merupakan sistem operasi mobile berbasis kornel Linux yang dikembangkan oleh AndroidInc dan kemudian di akuisisi oleh Google. Sistem operasi ini bersifat open source sehingga para programmer dapat membuat aplikasi secara mudah.

Media pembelajaran berupa aplikasi Android berbasis Adobe AIR (Adobe Integrated Runtime) dapat dijalankan pada perangkat bergerak berbasis Android. Sehingga media pembelajaran dapat dijalankan kapan pun dan dimana pun. Media pembelajaran ini termasuk dalam kategori media pembelajaran berbasis mobile learning. Hal ini sesuai dengan yang dinyatakan oleh (O'Malley, 2003: 6), yaitu suatu pembelajaran yang pembelajarnya (learner) tidak diam pada suatu tempat atau kegiatan pembelajaran yang terjadi ketika pembelajar mamanfaatkan perangkat teknologi bergerak.

Pengembangan media pembelajaran berbasis Android memungkinkan terciptanya multimedia pembelajaran yang lebih interaktif dan efektif dalam pembelajaran, salah satunya adalah pengembangan media game edukasi berbasis Android. Game adalah sebuah permainan yang berfungsi sebagai warming up (pemanasan), penghilang kejenuhan dalam materi yang melelahkan, mendukung peserta mentoring agar terlibat lebih aktif dan memberi 
respon (Susanto, 2009: 19). Aplikasi ini nantinya menyajikan berbagai contoh soal-soal ujian nasional yang bersumber dari salah satu buku, internet dan lain-lain. Kisi-kisi yang dijadikan acuan adalah kisi-kisi yang dikeluarkan oleh pemerintah sesuai dengan tahun ajaran yang berjalan. Aplikasinya berupa game kuis layaknya simulasi ujian nasional. Melalui Play Store, pengguna dapat mengunduh berbagai macam aplikasi dengan gratis ataupun berbayar tergantung dari developer atau pembuatnya. Selain itu juga pengguna dapat berbagi melalui perangkat transfer data antar telepon (Bluetooth).

Berdasarkan perumusan masalah yang telah diuraikan di atas, maksud dan tujuan penelitian dalam Perancangan Media Siap UN SMP Berbasis Android, yaitu untuk merancang media siap UN SMP berbasis Android, supaya efektif maka dibuat dengan inovasi baru mengenai desain pembelajaran yang tepat sesuai dengan pembelajaran Matematika pada peserta didik Sekolah Menengah Pertama.

\section{Tinjauan Pustaka}

Belajar adalah suatu proses usaha yang dilakukan seseorang untuk memperoleh suatu perubahan tingkah laku yang baru secara keseluruhan, sebagai hasil pengalamannya sendiri dalam interaksi dengan lingkungannya (Slameto, 2010: 12). Sedangkan (Hasbullah dan Wiratomo, 2015: 10), "belajar merupakan suatu aktivitas mental dan psikis yang menuntut keterlibatan intelektual anak secara optimal, serta membutuhkan banyak latihan yang teratur, tekun dan terukur sehingga menghasilkan perubahan-perubahan pengetahuan, pemahaman dan keterampilan peserta didik terhadap materi pelajaran atau kegiatan.

Pembelajaran menurut Hamalik (2011: 54) merupakan suatu kombinasi yang tersusun unsurunsur manusiawi, fasilitas, perlengkapan, dan prosedur yang saling mempengaruhi untuk mencapai tujuan dari pembelajaran itu sendiri. Sedangkan menurut Dimyati dan Mudjiono (2006: 157) pembelajaran adalah proses yang diselenggarakan oleh guru untuk membelajarkan peserta didik dalam belajar bagaimana memperoleh dan memproses pengetahuan, keterampilan, dan sikap.

Nikson (dalam Ratumanan, 2002: 3) mengemukakan bahwa pembelajaran matematika adalah suatu upaya membantu peserta didik untuk mengkonstruksikan (membangun) konsepkonsep atau prinsip-prinsip matematika dengan kemampuannya sendiri melalui proses interalisasi sehingga konsep atau prinsipnya itu kembali terbangun. Hal ini senada dengan Bruner (dalam Hudoyo, 2000: 56) yang menyatakan bahwa pembelajaran matematika adalah belajar tentang konsep dan struktur matematika yang terdapat dalam materi yang dipelajari serta mencari hubungan antara konsep dan struktur matematika di dalamnya. Sedangkan menurut Cobb (dalam Suherman, dkk, 2003: 71) pembelajaran matematika sebagai proses pembelajaran yang melibatkan peserta didik secara aktif mengkonstruksi pengetahuan matematika.

Dari uraian di atas disimpulkan bahwa pembelajaran matematika merupakan proses aktif dan konstruktif dimana peserta didik terlibat di dalamnya sehingga paham dan mampu menyelesaikan permasalahan yang dihadapi.

Media pembelajaran adalah segala sesuatu yang dapat digunakan untuk menyalurkan pesan dari pengirim ke penerima sehingga dapat merangsang pikiran, perasaan, perhatian, dan minat peserta didik sedemikian rupa sehingga proses belajar terjadi dalam rangka mencapai tujuan pembelajaran secara efektif (Sukiman, 2012: 29). Menurut Miarso (2009: 458), media pembelajaran dapat diartikan segala sesuatu yang digunakan untuk menyalurkan pesan serta dapat merangsang pikiran, perasaan, perhatian, dan kemauan si belajar sehingga dapat mendorong terjadinya proses belajar yang disengaja, bertujuan dan terkendali. 
Dari beberapa definisi di atas dapat disimpulkan bahwa media pembelajaran merupakan seperangkat alat bantu atau pelengkap baik tercetak maupun audiovisual yang dapat merangsang peserta didik untuk mencapai tujuan pembelajaran.

Penggunaan media pembelajaran dalam proses pembelajaran dimaksudkan untuk membantu guru dalam menyampaikan materi kepada peserta ddidik. Peserta didik akan lebih dimudahkan dalam memahami materi yang disampaikan menggunakan media. Hal tersebut karena media pembelajaran memiliki beberapa manfaat untuk mencapai tujuan pembelajaran. Penggunaan media pembelajaran dalam proses belajar mengajar dapat membangkitkan motivasi dan rangsangan kegiatan belajar mengajar dan bahkan membawa pengaruh-pengaruh psikologis terhadap peserta didik. Selain itu, media pembelajaran juga dapat membuat peserta didik meningkatkan pemahaman, menyajikan data dengan menarik dan terpercaya, memudahkan penafsiran data dan memadatkan informasi (Arsyad, 2005: 16). Dengan kata lain, penyajian materi pelajaran dengan menggunakan media dapat menciptakan pembelajaran yang lebih menarik, sehingga dapat meningkatkan minat serta rasa ingin tahu peserta didik yang diikuti peningkatan motivasi peserta didik untuk mempelajari materi tersebut.

Game Edukatif merupakan suatu permainan yang mengintegrasikan dan mengkombinasikan materi pelajaran ke dalam komponen-komponen permainan tersebut (Riva, 2012: 12). Menurut Agus (2011: 19) suatu permainan (game) dikatakan edukatif jika permainan itu dapat mendayagunakan dan mengasah kemampuan fungsi otak kiri sebagaimana mestinya. Dari pendapat di atas, dapat disimpulkan bahwa suatu game dapat disebut sebagai game edukatif ketika game tersebut mampu mengintegrasikan materi pelajaran ke dalam komponennya sehingga dapat mengasah fungsi otak kiri. Dapat disimpulkan pula bahwa game edukatif adalah game yang digunakan untuk membelajarkan pemainnya.

Android menurut Satyaputra dan Aritonang (2014 : 2) adalah sebuah sistem operasi untuk smartphone dan tablet. Sistem operasi dapat diilustrasikan sebagai jembatan antara device (perangkat) dan penggunanya, sehingga pengguna dapat berinteraksi dengan device-nya dan menjalankan aplikasi-aplikasi yang tersedia pada device. Android menyediakan platform terbuka bagi para pengembang untuk menciptakan aplikasi mereka.

Perkembangan Android dimulai dengan berdirinya Android Inc. pada Oktober 2003 dengan tujuan Mobile Device yang lebih pintar untuk menyaingi Symbian dan Windows Mobile yang populer pada saat itu dimana iPhone dan Blackberry belum dirilis. Pada tahun 2005, Android diakusisi oleh Google, pengembangan terus dilanjutkan sampai Android versi beta diluncurkan pada tanggal 5 November 2007. Hingga saat ini tanggal 5 November diperingati sebagai hari jadi Android. Seminggu setelahnya yaitu pada tanggal 12 November 2007 Android SDK (Software Development Kit) diluncurkan, sehingga pengguna dapat membuat dan mengembangkan aplikasi-aplikasi Android mereka sendiri (Satyaputra dan Aritonang, 2014: 5).

\section{Metodologi Penelitian}

Waktu penelitian dilakukan pada Maret 2016 sampai dengan Agustus 2016. Penelitian ini merupakan jenis penelitian pengembangan yang berorientasi pada pengembangan produk. Produk yang dihasilkan berupa media pembelajaran matematika berbasis Android yang memuat aspek entertainment (hiburan) dan games (Permainan) pada materi soal-soal Ujian Nasional tingkat Sekolah Menengah Pertama.

Model pengembangan yang digunakan dalam mengembangkan media pembelajaran ini adalah model pengembangan ADDIE, yaitu model pengembangan yang terdiri dari lima tahapan yangmeliputi analisis (analysis), desain (design), pengembangan (development), 
implementasi (implementation), dan evaluasi (evaluation). Model pengembangan ADDIE dikembangkan oleh Dick and Carry pada tahun 1996 untuk merancang sistem pembelajaran (Mulyatiningsih, 2011: 161).

Prosedur pengembangan media pembelajaran Soal UN (Ujian Nasional) game edukatif berbasis Android dengan prosedur penelitian tersebut dapat dilihat pada gambar di bawah:

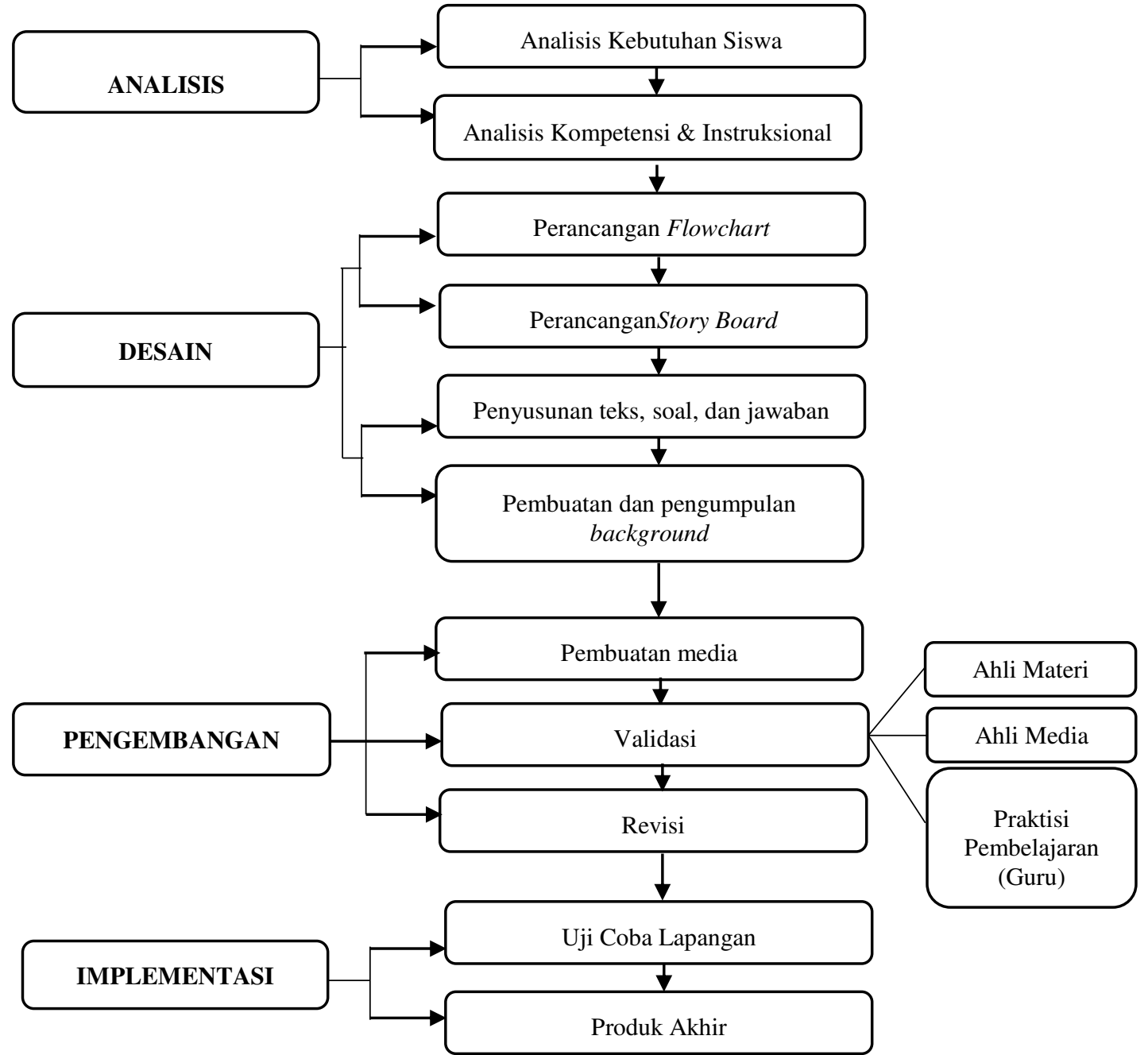

Gambar 1. Bagan Prosedur Pengembangan Produk Media Pembelajaran

Teknik pengumpulan data pada penelitian ini adalah menggunakan angket atau kuesioner. Angket ini digunakan untuk menilai media berdasarkan ahli materi, ahli media, dan praktisi pembelajaran atau guru.

Instrumen yang digunakan pada penelitian pengembangan ini untuk memperoleh data dari ahli media, ahli materi, dan praktisi pembelajaran atau guru. Sebagai bahan mengevaluasi produk atau media pembelajaran yang dikembangkan. Penilaian pada angket menggunakan skala Likert (skala 5). Alternatif jawaban yang digunakan dalam angket yaitu: SS (Sangat Setuju $)=5$, S $($ Setuju $)=4$, N $($ Netral $)=3$, TS $($ Tidak Setuju $)=2$, dan STS $($ Sangat Tidak Setuju $)=1$. Pada angket tidak digunakan pertanyaan negatif, karena angket ini digunakan untuk menilai kelayakan media pembelajaran.

\section{Hasil dan Pembahasan \\ Perancangan media "Siap UN SMP" berbasis Android}


Perancangan media "Siap UN SMP" berbasis Android ini merupakan adaptasi dan hasil modifikasi dari langkah-langkah penelitian dan pengembangan model ADDIE yaitu dengan tahapan a) analysis (analisis), b) design (desain), c) development (pengembangan), d) implementation (implementasi), e) evaluasi (evaluation). Peneliti membatasi hanya sampai pada langkah implementasi. Langkah-langkah pengembangan dijabarkan sebagai berikut:

\section{Tahap Analisis (analysis)}

Pada tahap analisis, dilaksanakan analisis kebutuhan, analisis kompetensi dan instruksional. Berikut penjabaran dari masing-masing tahap analisis.

a. Analisis kebutuhan

Analisis kebutuhan berkaitan dengan permasalahan dan karakteristik peserta didik, perangkat keras (hardware) serta perangkat lunak (software).

1) Permasalahan dan karakteristik peserta didik

Seiring dengan perkembangan teknologi, peserta didik usia SMP memiliki kecenderungan berhubungan dengan smartphone. Dari hasil pengamatan, penggunaan smartphone dapat menyita waktu belajar peserta didik, misalnya hanya untuk memutar musik, bermain game, dan mengakses berbagai macam media sosial. Peserta didik yang merasa jenuh ketika melakukan pembelajaran akan lebih tertarik untuk melakukan hal-hal lain seperti mengobrol dengan teman atau melakukan kegiatan lain dengan smartphonenya. Hal ini mengindikasikan bahwa smartphone lebih menarik daripada buku, hal ini juga dapat diantisipasi dengan membuat media pembelajaran di smartphone. Smartphone yang digunakan menggunakan sistem operasi android. Dipilihnya android karena pengguna android merupakan yang terbesar dari sistem operasi yang lain. Pembuatan dan pengembangan media pembelajaran dengan memanfaatkan teknologi dapat meningkatkan kualitas proses pembelajaran. Dengan perancangan media "Siap UN SMP" berbasis android ini diharapkan dapat meningkatkan kualitas proses pembelajaran. Dengan nilai tambah media ini dapat digunakan kapan saja dan di mana saja karena sifatnya yang portable. Proses penyebaran cukup mudah karena ukurannya yang relatif kecil. Proses penyebaran dapat menggunakan Bluetooth, kabel data, diunduh dari Play Store maupun link-link lainnya yang selanjutnya di install secara online.

2) Perangkat keras (hardware) dan perangkat lunak (software)

Perangkat keras (hardware) yang digunakan untuk membuat media pembelajaran ini adalah:

a) Intel ${ }^{\circledR}$ Core $^{\mathrm{TM}} \mathrm{i} 3-4030 \mathrm{CPU} @ 1,90 \mathrm{GHz}$

b) RAM 4 GB

c) HDD $500 \mathrm{~GB}$

d) VGA NVIDIA GEFORCE 820M 2 GB

Perangkat lunak (software) yang dibutuhkan adalah sebagai berikut:

a) Perangkat lunak sistem operasi:

Android

b) Perangkat lunak pembuat media pembelajaran:

Website Appypie.com

c) Perangkat lunak pembuat gambar

Gambar PNG; Adobe Illustrator CS6 \& Adobe Photoshop CS6

d) Perangkat lunak pembuat Documentatau e-book

E-book; Microsoft Word dan PDF (Portable Document Format)

b. Analisis Kompetensi dan Instruksional

Analisis kompetensi dan instruksional berkaitan dengan standar kompetensi dan kompetensi dasar yang akan dimuat dalam media. Pada tahap analisis kompetensi 
dilakukan kajian terhadap kompetensi minimal yang harus dicapai siswa sesuai dengan standar isi yang ditetapkan oleh Badan Standar Nasional Pendidikan (BSNP). Soal Ujian nasional diambil dari buku karya Prasetya Adhi Nugroho, S.Pd, Si dan Dedy Gunarto, S.Si yang berjudul Big Bank Soal+Bahas Matematika SMP atau MTs, penerbit Wahyumedia, Jakarta.

\section{Tahap Desain (Design)}

Tahap desain merupakan tahap perancangan media yang meliputi pembuatan flowchart, pembuatan desain media secara keseluruhan (storyboard), penyusunan soal dan jawaban, pengumpulan dan pembuatan background, gambar, dan tombol, serta penggunaan musik dan suara.

a. Pembuatan Flowchart

Flowchart merupakan bagan yang terdiri dari simbol-simbol tertentu yang menunjukkan langkah-langkah suatu prosedur atau program sehingga memudahkan dalam proses pengembangan media.

b. Pembuatan desain media (Storyboard)

Storyboard menggambarkan secara keseluruhan hubungan antara bagian dalam media. Storyboard dibuat untuk memudahkan proses pembuatan media selanjutnya dan berfungsi sebagai peta pada panduan pembuatan media.

c. Penyusunan soal dan pembahasan jawaban

Soal dan pembahasan jawaban yang dimuat dalam media disusun dari buku karya Prasetya Adhi Nugroho, S.Pd, Si dan Dedy Gunarto, S.Si yang berjudul Big Bank Soal+Bahas Matematika SMP atau MTs, penerbit Wahyumedia, Jakarta. Seluruh soal yang akan dimuat dalam media langsung dimasukkan ke dalam menu penginputan soal yang telah disediakan oleh situs pengembang aplikasi. Untuk simbol matematika dibuat dengan bantuan Character Map atau tombol Fn+Num Lk+kode pada keyboard. Pembahasan jawaban yang akan dimuat dibuat diketik dalam Ms. Word selanjutnya diubah kedalam format .pdf (portable document format).

d. Pengumpulan dan pembuatan background, gambar, dan tombol

Gambar yang disajikan dalam media dirancang dengan mengkombinasikan gambar hasil unduhan dari berbagai sumber. Pembuatan dan pengkombinasian gambargambar ini dilakukan dengan menggunakan program Adobe Illustrator CS6. Seluruh gambar dibuat dalam format portable network graphics (.png). memori penyimpanan gambar dalam format ini relative lebih kecil dan kualitas yang lebih baik dibandingkan dengan format lain seperti JPEG (.jpeg).

e. Penggunaan musik

Penggunaan musik ini terdapat dalam menu 'Soal' berupa musik instrumental yang didapat dari berbagai sumber. Penggunaan musik instrumental ditujukan agar tidak mengganggu dan memecah konsentrasi pengguna terutama dalam mengerjakan soal.

\section{Tahap Pengembangan (Development)}

a. Pembuatan Media Pembelajaran "Siap UN SMP"

Media ini diberi nama "Siap UN SMP". Seluruh komponen yang telah dipersiapkan pada tahap desain dirangkai menjadi satu kesatuan media dengan template yang telah disediakan oleh website Appypie.com. Seluruh komponen dirangkai menjadi satu kesatuan media sesuai dengan storyboard dan flowchart melalui serangkaian tahapan.

Soal, pambahasan, gambar, dan background yang akan dimuat dalam media dimasukkan ke dalam template yang ada dalam website Appypie.com. Font yang digunakan yaitu verdana.Media pembelajaran dimuat dalam format file APK (.apk) dan siap untuk diinstal pada smartphone dengan sistem operasi Android sesuai dengan spesifikasi yang telah ditentukan. Tampilan menu kerja pada website Appypie.com dapat dilihat pada: 


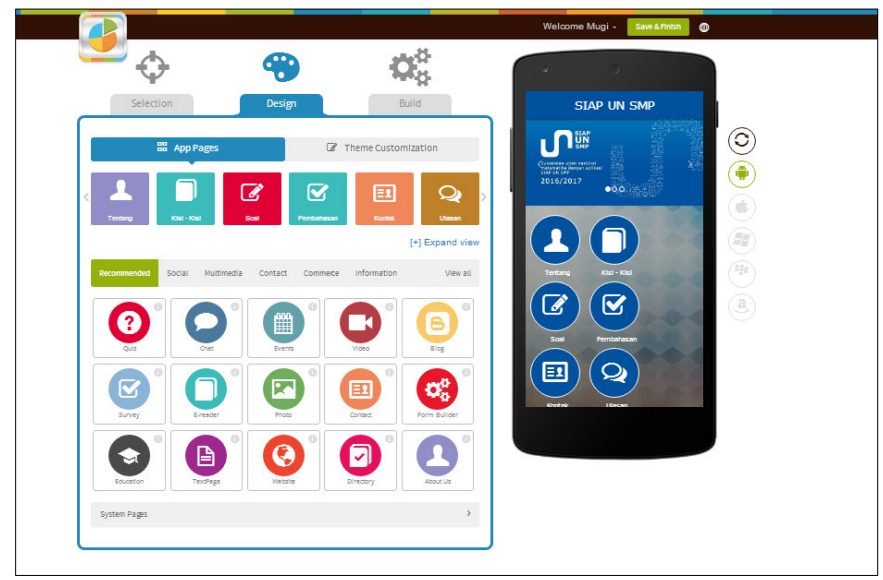

Gambar 2. Layar Kerja Appypie.com

Pada tahap pembuatan media terdapat 4 kegiatan yaitu pembuatan antarmuka, pengaturan (Setting), pengujian (testing), dan deploying line.

b. Validasi

\section{1) Validasi Ahli Media}

Validasi media dilakukan dengan mengisi angket yang menggunakan skala Likert dengan 5 alternatif jawaban yaitu sangat setuju, setuju, netral, tidak setuju, dan sangat tidak setuju. Angket untuk ahli media memiliki 24 indikator penilaian yang dikelompokkan menjadi 2 aspek yaitu aspek perangkat lunak dan aspek komunikasi visual. Hasil rekapitulasi dan analisis validasi dari ahli media sebagai berikut:

Tabel 1. Hasil Validasi Ahli Media

\begin{tabular}{llccc}
\hline \multicolumn{1}{c}{ No. } & Aspek & Jumlah Nilai & Rata-Rata Nilai & Kategori \\
\hline 1. & Perangkat Lunak & 52 & 4,333 & Sangat Layak \\
2. & Komunikasi Visual & 54 & 4,5 & Sangat Layak \\
\hline Total & & 106 & 4,417 & Sangat Layak \\
\hline
\end{tabular}

Sumber: Data Primer yang diolah

2) Validasi Ahli Materi

Validasi yang dilakukan oleh ahli materi yaitu dengan mengumpulkan saran atau pendapat dari ahli materi untuk melakukan revisi. Angket yang digunakan menggunakan skala Likert dengan 5 alternatif jawaban yaitu sangat setuju, setuju, netral, tidak setuju, sangat tidak setuju. Angket untuk ahli materi memiliki 15 indikator penilaian yang dikelompokkan menjadi 3 aspek yaitu meliputi aspek soal, aspek bahasa, dan aspek keterlaksanaan. Hasil rata-rata validasi ahli materi terlampir pada tabel berikut:

Tabel 2. Hasil Validasi Ahli Materi

\begin{tabular}{llccc}
\hline No. & \multicolumn{1}{c}{ Aspek } & Jumlah Nilai & Rata - Rata Nilai & Kategori \\
\hline 1. & Soal & 37 & 4,625 & Sangat Layak \\
2. & Bahasa & 10 & 5,000 & Sangat Layak \\
3. & Keterlaksanaan & 24 & 4,800 & Sangat Layak \\
\hline Total & & 106 & 4,733 & Sangat Layak \\
\hline
\end{tabular}

Sumber: Data Primer yang diolah

3) Validasi Praktisi Pembelajaran (Guru)

Validasi praktisi dengan mengumpulkan saran atau pendapat untuk melakukan revisi terhadap media pembelajaran yang telah dibuat. Angket yang digunakan menggunakan skala Likert dengan 5 alternatif jawaban yaitu sangat setuju, setuju, netral, tidak setuju, dan sangat tidak setuju, angket untuk guru praktisi pembelajaran matematika memiliki 23 indikator penilaian yang dikelompokkan 
menjadi 3 aspek yaitu aspek rekayasa perangkat lunak, aspek desain pembelajaran, dan aspek komunikasi visual. Hasil rata-rata validasi dari praktisi pembelajaran matematika adalah sebagai berikut.

Tabel 3. Hasil Validasi Praktisi Pembelajaran (Guru)

\begin{tabular}{llccc}
\hline No. & \multicolumn{1}{c}{ Aspek } & Jumlah Nilai & Rata - Rata Nilai & Kategori \\
\hline 1. & Rekayasa & 28 & 4,667 & Sangat Layak \\
2. & Perangkat Lunak & & & Desain \\
3. & Kembelajaran & 38 & 4,222 & Sangat Layak \\
\hline Total & & 36 & 4,500 & Sangat Layak \\
\hline
\end{tabular}

Sumber: Data Primer yang diolah

c. Revisi atau Saran Perbaikan

Dari hasil penyebaran angket yang dilakukan terhadap Ahli Media, Ahli Materi dan Praktisi Pembelajaran (Guru), terdapat beberapa sara perbaikan atau revisi. Dikarenakan terbatasnya waktu dan tenaga ahli dalam pengembangan media, saran yang peneliti terima saat ini ditampung terlebih dahulu untuk nantinya dilakukan perbaikan sesuai saran. Berikut adalah beberapa saran perbaikan dari penguji:

1) Revisi atau Saran Perbaikan dari Ahli Media

a) Digunakan adanya tombol preview jika untuk kembali ke soal.

b) Adanya tombol pintas untuk memilih soal.

c) Lebih dikembangkan dalam variasi soal dan accessibility.

2) Revisi atau Saran Perbaikan dari Ahli Materi

a) Pengembangan tingkat level

b) Adanya tombol back

3) Revisi atau Saran Perbaikan dari Praktisi Pembelajaran (Guru)

Tidak ada saran perbaikan dari Praktisi Pembelajaran (Guru)

\section{Tahap Implementasi (Implementation)}

Tahap implementasi dilaksanakan dengan mengunggah aplikasi "Siap UN SMP" ke playstore. Pengguna yang telah mengunduh aplikasi, diminta untuk memberikan rating dan menulisakan review pada halaman ulasan yang tersedia di playstore.

\section{Pembahasan}

Perancangan media "Siap UN SMP" berbasis android ini diharapkan dapat meningkatkan kualitas proses pembelajaran. Apalagi media ini dapat digunakan kapan saja dan di mana saja karena sifatnya yang portable. Proses penyebaran cukup mudah karena ukurannya relatif kecil. Proses penyebaran dapat menggunakan Bluetooth, kabel data, link, Barcode Scan maupun diunduh dari play store. Menurut Purbasari, dkk (2013: 8), dengan adanya pengembangan aplikasi pengembangan pada perangkat mobile diharapkan dapat meningkatkan manfaat perangkat mobile dalam bidang pendidikan dan dapat memberikan motivasi belajar siswa adanya. Sedangkan menurut Busran, dkk (2015: 78), penggunaan objek dalam sebuah media pembelajaran dapat meningkatkan perhatian, perasaan, dan pikiran untuk belajar dan terjadi pembelajaran yang lebih efektif dan efisien. Kelayakan rancangan media "Siap UN SMP" diketahui melalui tahap validasi. Hasil kelayakan pada masing-masing tahap penilaian secara keseluruhan dapat dilihat pada tabel dibawah ini:

Tabel 4. Kelayakan Media Pada Tahap Validasi

\begin{tabular}{llccc}
\hline \multicolumn{1}{c}{ No. } & \multicolumn{1}{c}{ Aspek } & Jumlah Nilai & Rata - Rata Nilai & Kategori \\
\hline 1. & Penilaian Ahli Media & 106 & 4,41 & Sangat Layak \\
2. & Penilaian Ahli Materi & 71 & 4,73 & Sangat Layak \\
3. & Penilaian Praktisi & 102 & 4,43 & Sangat Layak \\
& Pembelajaran (Guru) & & & Sangat Layak \\
\hline Total & & 106 & 4,58 & \\
\hline
\end{tabular}


Berdasarkan tabel di atas, dapat dilihat bahwa media pembelajaran "Siap UN SMP" berbasis android memperoleh kategori Sangat Layak untuk tahap penilaian ahli media dengan rerata skor 4,41 dan untuk tahap penilaian oleh ahli materi memperoleh kategori Sangat Layak dengan rerata skor 4,73 . Kemudian untuk tahap penilaian oleh praktisi pembelajaran matematika memperoleh kategori Sangat Layak dengan rerata skor 4,43 dan secara keseluruhan dari ketiga tahap penilaian yang dilakukan oleh ahli media, ahli materi, dan praktisi pembelajaran matematika diperoleh rerata skor 4,58 yang masuk dalam kategori sangat layak.

Penilaian kelayakan media pada tiap tahap tersebut apabila ditampilkan dalam diagram batang dapat dilihat pada gambar di bawah ini:

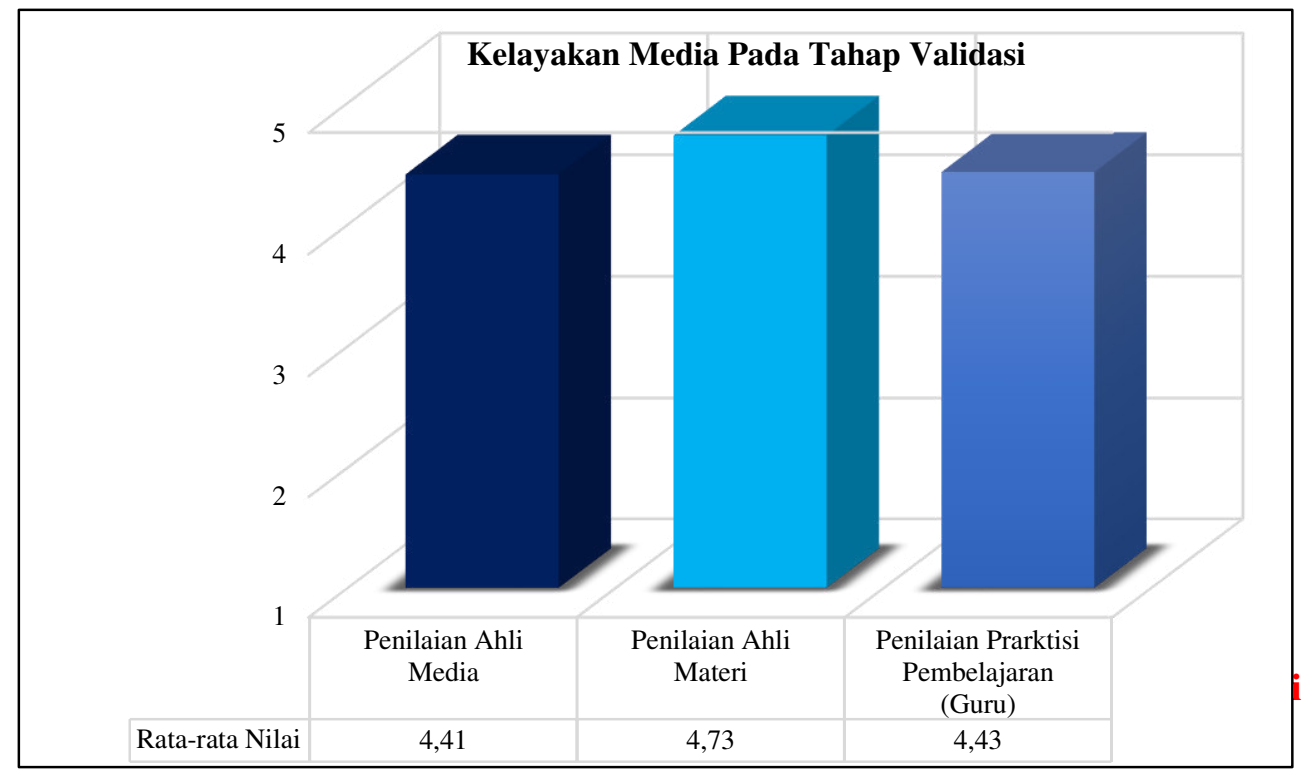

Gambar 3. Diagram Batang Kelayakan Media pada Tiap Tahap Validasi

Berdasarkan penilaian ahli media, ahli materi, dan praktisi pembelajaran matematika dapat disimpulkan bahwa perancangan media"Siap UN SMP" berbasis android "Sangat Layak" digunakan sebagai media pembelajaran untuk peserta didik terutama peserta didik SMP dalam persiapan menghadapi ujian nasional, serta game edukatif ini dapat disebarluaskan sebagai salah satu alternatif media pembelajaran kepada peserta didik SMP di berbagai sekolah yang ada di Indonesia.

\section{Simpulan dan Saran \\ Simpulan}

Pengembangan game edukatif "Siap UN SMP" berbasis android pada materi jurnal penyesuaian melalui empat tahap yaitu Analysis. Didasarkan pada analisis kebutuhan, dan analisis kompetensi dan instruksional, maka diperoleh hasil bahwa kebanyakan dari peserta didik usia SMP merupakan pengguna smartphone, tetapi penggunaan smartphone belum dimanfaatkan secara maksimal dalam kegiatan belajar khususnya dalam persiapan ujian nasional. Design, pada tahap ini merancang media yang meliputi pembuatan flowchart, pembuatan desain media secara keseluruhan (storyboard), penyusunan soal, dan jawaban, pengumpulan dan pembuatan background, gambar dan tombol, serta penggunaan musik. Development, pada tahap ini membuat media pembelajaran "Siap UN SMP" menggunakan hardware dengan spesifikasi dan bantuan situs pengembangyaitu Appypie.com. Implementation, pada tahap ini peneliti mengimplementasikan media dengan mengunggah 
"Siap UN SMP" di Playstore, melihat rating dan review yang diberikan pengguna, menunjukkan "Siap UN SMP" diterima dengan respon positif.

Saran

Berdasarkan kualitas media, kelemahan, dan keterbatasan penelitian yang telah dibahas sebelumnya, peneliti dapat memberikan beberapa saran pemanfaatan dan pengembangan media lebih lanjut sebagai berikut:

1. Game edukatif "Siap UN SMP" ini perlu dikembangkan lebih lanjut pada tampilan 3 dimensi (3D) sehingga dapat memuat animasi bergerak dan video.

2. Game edukatif "Siap UN SMP" perlu dikembangkan lebih lanjut sehingga tidak hanya dapat di unduh di playstore bagi pengguna Android saja, tetapi juga dapat di unduh appstore bagi pengguna Apple.

\section{Daftar Pustaka}

Agus, N. C. (2011). Gudang Permainan Kreatif Khusus Asah Otak Kiri Anak. Yogyakarta: Flashbooks.

Arsyad, Ashar. (2005). Media Pembelajaran. Jakarta: Raja Grafindo Persada.

Busran, dkk. (2015). Rancang Bangun Aplikasi Pembelajaran Iqra Untuk Anak Usia Dini Berbasis Android. Jurnal Momentum, Vol. 17 No. 1 Tahun 2015. 78-83.

Dimyati dan Mudjiono. (2006). Belajar dan Pembelajaran. Jakarta: Rineka Cipta.

Hamalik, Oemar. (2011). Psikologi Belajar Mengajar. Bandung: Sinar Baru Algesindo.

Hasbullah, dan Wiratomo, Y. (2015). Metode, Model, dan Pengembangan Model Pembelajaran Matematika. Jakarta: Unindra Press.

Hudoyo, Herman. (2000). Pengembangan Kurikulum dan Pembelajaran Matematika. Malang: Penerbit Universitas Negeri Malang.

Kominfo.go.id. (2014). Pengguna Internet di Indonesia Capai 82 Juta. https://kominfo.go.id/content/detail/3980/kemkominfo-pengguna-internet-diindonesia-capai-82-juta/0/berita_satker. Diakses pada tanggal 13 Juni 2016 pukul 21:05 WIB.

Miarso, Yusufhadi. (2009). Menyemai Benih Teknologi Pendidikan. Jakarta: Kencana.

Mulyatiningsih, Endang. (2011). Metode Penelitian Terapan Bidang Pendidikan. Bandung: Alfabeta.

O'Malley,C, dkk. (2003). Guidelines for Learning/Teaching/Tutoring in a Mobile Environtment Online, http://www.mobilearn.org/download/results/guidelines.pdf. Diakses pada tanggal 17 Agustus 2016.

Purbasari, Rohmi Julia, dkk. (2013). Pengembangan Aplikasi Android sebagai Media Pembelajaran Matematika pada Materi Dimensi Tiga untuk Siswa SMA Kelas X, http://jurnal-online.um.ac.id>data $>$ artikel. Diakses tanggal 13 Maret 2017

Ratumanan. (2002). Pengantar Penelitian Ilmiah Dasar, Metode dan Teknik. Bandung: Tarsito.

Riva, Iva. (2012). Koleksi Games Edukatif di Dalam dan Luar Sekolah. Yogyakarta: FlashBooks.

Satyaputra dan Aritonang. (2014). Beginning Android Programming with ADT Budle. Jakarta: Elex Media Komputindo.

Slameto. (2010). Belajar dan Faktor-Faktor yang Mempengaruhinya. Jakarta: Rineka Cipta.

Suherman, Erman, dkk. (2003). Strategi Pembelajaran Matematika Kontemporer. Bandung: JICA.

Sukiman. (2012). Pengembangan Media Pembelajaran. Yogyakarta: Pedagogia

Susanto, Eko. (2009). 60 Games untuk Mengajar Pembuka dan Penutup Kelas. Yogyakarta: Lumbungkita. 